\title{
Conceptualising Gifted Student (Dis) Engagement through the Lens of Learner $(\mathrm{Re})$ Engagement
}

\author{
Michelle Ronksley-Pavia ${ }^{1,2, * \mathbb{D}}$ and Michelle M. Neumann ${ }^{1,2} \mathbb{D}$ \\ 1 School of Education and Professional Studies, Griffith University, Brisbane 4222, Australia; \\ m.neumann@griffith.edu.au \\ 2 Griffith Institute for Educational Research (GIER), Griffith University, Brisbane 4222, Australia \\ * Correspondence: m.ronksley-pavia@griffith.edu.au
}

Received: 27 August 2020; Accepted: 24 September 2020; Published: 10 October 2020

\begin{abstract}
It is well-recognised that disengagement is a growing problem in schools across the globe. Furthermore, statistics show that nearly $60 \%$ of all gifted students are not actualising their potential, exposing the loss of potential for both the individual and society. While disengagement and underachievement are complex issues with no one root cause, it is well-established that when students are actively engaged in their learning, they learn more effectively. Talent actualisation is not guaranteed just because a student is gifted. As such there is heightened concern about student (dis)engagement, where there is a failure to adequately support (re)engagement so that gifted potential can develop into talent actualisation, which is evidenced through mastery. This conceptual article provides a new lens through which to explore (re)engagement opportunities for gifted students by conceptualising the interrelationship between three interconnected constructs: (1) four engagement dimensions (behavioural, affective, social, and cognitive); (2) Neihart and Betts' six profiles of the gifted; and (3) appropriate pedagogical approaches aimed at (re)engagement. The authors' focus on proposing new conceptualisations of these three interdependent constructs through a framework titled the (Re) Engagement Nexus Model. This model is intended as a starting point for future research in personalising (re)engagement opportunities for gifted learners and preventing underachievement and disengagement before it becomes entrenched.
\end{abstract}

Keywords: gifted and talented students; student engagement; underachievement; disengagement; (re)engagement; profiles of gifted learners; personalised learning

\section{Introduction}

Underachievement is a frequently researched topic in the field of gifted and talented education [1]. However, sometimes this research is not well-situated to school pedagogical practices, moreover the field is often clouded by ambiguous definitions and conceptualisations of underachievement [1]. Because underachievement signifies both psychosocial and educational features of gifted education pedagogical practices, it is important to explore the impact of student engagement in relation to underachievement.

The underachievement and disengagement of gifted students presents an enigma for the students themselves, their parents, and teachers [2]. The expectation for gifted students is that they, by their very nature of being gifted, should be showing sustained evidence of high academic achievement [3]. When this is not the case, the inconsistency between anticipated achievement and actual achievement is of concern due to the adverse impacts on school and life outcomes [3], and hopes for developing lifelong learners. While student engagement is influenced by a diverse range of demographic factors that cannot be changed (e.g., cultural background), student engagement can be seen as "an alterable class of variables" [3] (p. 224), that is impacted by different contexts (i.e., school, home, relationships); 
all of which are associated with academic outcomes and social belongingness [4]. In this article we explore the nexus between three interrelated components: (1). gifted students based on the broad Neihart and Betts' [5] six profiles; (2) gifted student engagement based on four engagement dimensions; and (3) appropriate pedagogical approaches for supporting the (re)engagement of gifted students. The multipart exploration of these three important components, to our knowledge, has not been previously explored. We begin by first defining gifted and talented students in the Australian context, then exploring engagement for gifted learners, before turning to conceptualising (dis)engagement and (re)engagement opportunities through personalised learning approaches at the nexus of the three components.

\section{Gifted and Talented Students}

Gifted students can be defined as those whose potential is in the top $10 \%$ of age peers [6]. In Australia, Gagné's Developmental Model of Giftedness (DMGT) [6] is the most accepted defining model for gifted and talented education [7]. The DMGT covers six domains of giftedness, under two headings: 1. Mental giftedness: (i) Intellectual (e.g., crystallised reasoning), (ii) Creative (e.g., problem-solving), (iii) Social (e.g., leadership), and (iv) Perceptual (e.g., hearing), and 2. Physical giftedness: (v) Muscular (e.g., strength and endurance) and (vi) Motor Control (e.g., speed and agility).

Within Gagné's DMGT, the differences between giftedness and talent are unpacked and clearly distinguished. Giftedness is the possession of outstanding natural abilities in at least one of the ability domains (e.g., Intellectual), to a degree that places an individual at least among the top 10\% of age peers-this is about a student's potential. On the other hand, talent is more about actual achievement, the outstanding mastery of abilities that have been systematically developed, in at least one field (e.g., Science and Technology), to a degree that places an individual at least among the top $10 \%$ of age peers - this refers to actualisation of gifted potential. For the purpose of this discussion we draw on Gagné's conception of giftedness as potential, and (re)engaging gifted students in learning so they can achieve mastery (talent), through systematically developing their gifted abilities. In order to do this, it is important that gifted student underachievement through (dis)engagement is addressed.

The two concepts of underachievement and (dis)engagement, are inherent within the centre of Gagné's DMGT where environmental catalysts (e.g., culture, pedagogy, relationships), and intrapersonal catalysts (e.g., motivation, volition, resilience), impact on the actualisation of talent through the talent development process. Both environmental and intrapersonal catalysts impact on the conceptualisation of underachievement and (dis)engagement in that these influence the development of giftedness into talent. Therefore, it is of paramount importance that gifted students are engaged in their learning, as it is a key aspect to preventing underachievement for gifted learners.

\section{3. (Re) Engaging Gifted Students}

It is well-recognised that disengagement is a growing problem in Australian schools, with up to $40 \%$ of students identified as being disengaged [8]. Furthermore, statistics show that nearly $60 \%$ of all gifted students are not achieving their potential [2]; research shows this is leading to "a loss of potential for both the individual and society as a whole" [9] (p. 163). As Gagné [6] recognises in his DMGT, talent actualisation is not guaranteed just because a student is gifted. This is where there is heightened concern about the inconsistency between anticipated actualisation of talent (in the form of achievement), and actual (under)achievement through the talent development process proposed in the DMGT, where giftedness may not be developed into talent (mastery).

While disengagement and underachievement are complex issues with no one root cause, it is well-recognised that when students are actively engaged in their learning, they learn more effectively [8], thus addressing (at least in part) underachievement. Furthermore, learner engagement is a driver of student learning outcomes [10]. Gifted students who are disengaged and underachieve exist in all regions of the globe, and are found within culturally diverse populations, communities with low socio-economic status, and individuals with disabilities $[2,11]$. 
Student engagement can be conceptualised through four interrelated dimensions: Behavioural engagement (e.g., participation), Affective engagement (e.g., student attitude), Social engagement (e.g., sense of belonging at school), and Cognitive engagement (e.g., self-regulation) [12]. The dimensions represent an interrelated and multidimensional conceptualisation of engagement, where students often move between and within the dimensions, exemplifying different elements within each dimension depending on the activity, and their interest and engagement [12]. Engagement has previously been conceptualised as a continuum model. This previous form of modelling appears to define desired exemplification of the elements within each dimension, prior to, and connected with the successive dimension on the continuum in a linear fashion. Continuum modelling is more suitable for viewing processes consisting of different stages or steps, one being achieved prior to or overlapping with the next [13], with the focal desired outcome of cognitive engagement. Yet, the complex interrelatedness of the four engagement dimensions means that a continuum model is not well-suited for exploring these complexities involved in the processes and elements of engagement. We propose a revisioning of the engagement continuum as a cyclical process (Figure 1).

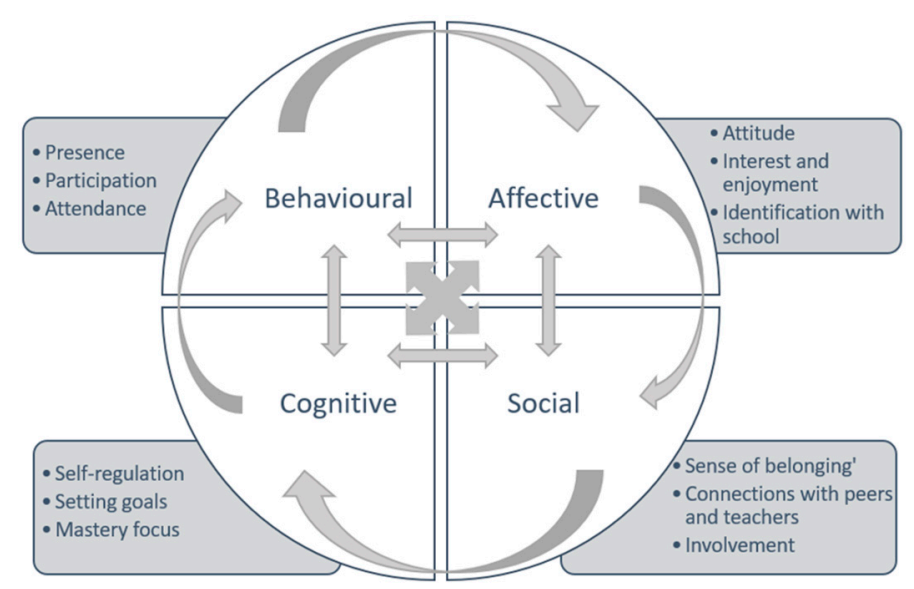

Figure 1. The Cyclical Model of Engagement showing the four interrelated dimensions of student engagement informed by $[12,14,15]$.

Our Cyclical Model of Student Engagement (Figure 1) shows a cyclical continuum, which enables the different elements across and within the engagement dimensions to be acknowledged and reconceptualised as non-sequential, complex, recurrent, and interconnected components. The cyclical process also recognises multiple outcomes within each dimension and across the dimensions to enable a more complex exploration of the dimensions and exemplified elements evident (or not) in the classroom. The following section unpacks the four dimensions across our Cyclical Model of Student Engagement.

The behavioural engagement dimension is related to what teachers see in their schools and classrooms; students participating in activities and class discussions, attending to the teacher and peers, on-task behaviour, involvement in school activities, as well as persevering when challenged in their learning [12]. These are said to be positive-involved behaviours, exemplified by students positively engaging in their learning. Behavioural engagement is often what educators refer to when they talk about student engagement, which is frequently reduced to a single factor, that of student attendance data [15]. While it is self-evident that students need to be in attendance to become engaged, (behaviourally present), as can be seen, there is much more to engagement than merely being marked present on the class roll.

The dimension of affective engagement is all about the learner and their emotions during learning. This dimension is strongly connected to student interest in and enjoyment of what they are learning and school-related activities (e.g., extra/co-curricular). Affective engagement is demonstrated through happiness, identification with school, a student's attitude, and both positive and negative connections to peers, teachers, school, and learning [14]. Students who are affectively engaged know why they 
are learning the content of any given lesson. Affective engagement is strongly connected to the use of digital technologies and can vary depending on what and how students are using these $[15,16]$. It is well understood that positive affective engagement is strongly connected to behavioural engagement [17]. Emotions like happiness, pride, and enthusiasm can drive student learning and connect them behaviourally, affectively, socially, and cognitively to both learning and school. Likewise, an absence of these positive emotions can lead to feelings of loneliness, sadness, and lack of identification with school and learning. This has implications for both engagement and student outcomes.

The social engagement dimension represents a student's sense of belonging and connectedness to school, including peers and teachers. This dimension is intimately connected to affective engagement as together both factors produce feelings of connection to school and a sense of inclusion [12]. In the classroom, social engagement is demonstrated when students show an understanding of the social conventions of learning: cooperative learning, taking turns, arriving on time to class, and listening to others [12]. Like affective engagement, a lack of social engagement can lead to students' experiencing isolation and loneliness [18].

The cognitive engagement dimension embodies the culmination of student engagement: mastery and autonomy. In the cognitive engagement dimension, students are demonstrating learning by choice, applying processes of deep thinking, self-regulating behaviours, purposefully setting goals and mastering what they are learning [14]. Through their use of metacognitive strategies students who are cognitively engaged show a strong sense of agency and preference for challenge at school. Their application of higher order thinking processes becomes automatic as they demonstrate mastery of the learning. Mastery is a key word here, in both the cognitive engagement dimension and moving to talent development: actualisation of gifted potential. According to Gagné's DMGT [6], the move from giftedness (as potential) to talent, evidenced in achievement, requires catalysts, such as an engaging learning environment and learning activities, where teachers should be making explicit and deliberate efforts to engage gifted learners across the engagement dimensions.

\section{Conceptualising Disengagement and Underachievement for Gifted Students}

The four interconnected engagement dimensions exemplified in our Cyclical Model of Student Engagement have key implications for both supporting gifted students at risk for underachievement, as well as designing and implementing suitable pedagogical approaches for sustaining (re)engagement [3]. Gifted students, who often experience cognitive engagement earlier in their learning than other students, can demonstrate 'early' mastery of the content (or already know the content) [19]. As Gross [20] pointed out, gifted students "come to school expecting to learn something new each day rather than to review and practise previous learning and skills" (p. 43). This can lead to early disengagement and subsequent underachievement. Gifted students need to be sufficiently challenged with learning opportunities that facilitate behavioural, affective, social, and cognitive engagement.

Identifying gifted students who are at-risk or who have disengaged can be problematic. These students frequently appear to be behaviourally engaged (e.g., on task), affectively engaged (e.g., positive reactions to teachers), and socially engaged (e.g., involved in their learning) and there may even be some signs of cognitive engagement (e.g., goal setting). Yet, their classwork or assessment results may not provide positive outcomes of this apparent engagement. This could be evidence of disengagement and underachievement. One approach to identify levels of disengagement is through student underachievement. This can be measured by looking at the difference between a gifted student's ability and their performance and achievement [21]. However, this is unreliable at best given that disengaged gifted students can fly under the radar [21], achieving satisfactorily (e.g., achieving Bs and Cs), but not demonstrating what their parents and some teachers know they can do. Since disengagement and underachievement often begins in primary (elementary) school it is important to be able to recognise and intervene early with appropriate pedagogical practices and support strategies. This is where an understanding of the engagement dimensions and broad gifted 
learner profiles is important. We now turn to exploring the interrelated engagement dimensions in relation to gifted learners conceptualised through our Cyclical Model of Student Engagement.

\section{The Engagement Dimensions and Gifted Student Profiles}

A useful framework for understanding how our Cyclical Model of Student Engagement further connects to gifted students is to explore these concepts in connection with Neihart and Betts' [5] Revised Profiles of the Gifted and Talented. It is important to note that gifted students are not (and should not) be defined by these six profiles as their characteristics, personalities, and needs vary across the course of their education [11]. Furthermore, each gifted student should have their own individual profile developed in conjunction with the student themselves and stakeholders, which is based on the specific learning characteristics and needs of each student. However, Neihart and Betts' six profiles provide one useful way of considering some of the unique characteristics and opportunities for (re)engaging gifted students.

The Neihart and Betts [5] gifted profiles are valuable in understanding disengagement and underachievement for gifted students: Profile I Successful Learner (Table 1), Profile II Creative (Table 2), Profile III Underground (Table 3), Profile IV At-Risk (Table 4), Profile V Twice-Exceptional (Table 5), and Profile VI Autonomous Learners (Table 6). While we recognise that these profiles are generalised and broad, they do provide some initial starting points for teachers to ascertain individual student needs and develop opportunities to (re)engage gifted students through personalised pedagogical approaches.

Applying Neihart and Betts' six profiles enables us to demonstrate that some of these learners share common characteristics, which connect directly with the four engagement dimensions. For example: low self-esteem connects directly to affective engagement and social engagement); lack of intrinsic motivation connects to affective engagement; erratic attendance connects with behavioural engagement; limited self-regulation connects to cognitive engagement; and lack of a sense of belonging at school connects with social engagement. These connections are considered further in the following section.

The Successful gifted learner profile (Table 1), suggests a key characteristic of high motivation for these students. However, this motivation is extrinsic, related to pleasing the teacher, rather than intrinsic motivation. It is essential to develop intrinsic motivation, so students are aware of why they are learning the topic, what it means and the relevance of this new learning to their own lives. This is intrinsically connected to the behavioural, affective, social, and cognitive engagement dimensions [12] in our Cyclical Model of Student Engagement.

Table 1. Profile I Successful gifted profile characteristics mapped to the four engagement dimensions informed by the following references $[5,11,12,15]$.

\begin{tabular}{|c|c|c|c|c|c|}
\hline & & Characteristics & $\begin{array}{l}\text { Behavioural } \\
\text { Engagement }\end{array}$ & Affective Engagement & Social Engagement \\
\hline $\begin{array}{l}\text { Profile I: } \\
\text { Successful }\end{array}$ & $\begin{array}{ll}\text { - } & \text { Complacent } \\
\text { - } & \text { Strong academic } \\
\text { - } & \text { self-concept } \\
\text { - } & \text { Motivated to } \\
\text { achieve } \\
\text { - } & \text { Conformist } \\
\text { - } & \text { Well-behaved } \\
\text { - } & \text { Achieves } \\
\text { significantly below } \\
\text { ability }\end{array}$ & $\begin{array}{ll}\text { - } & \text { Needs teacher } \\
\text { approval } \\
\text { - } & \text { Extrinsically } \\
\text { motivated } \\
\text { - } & \text { Conformist } \\
\text { - } & \text { Remains in } \\
\text { comfort zone } \\
\text { - Chooses safe } \\
\text { activities }\end{array}$ & $\begin{array}{ll}\text { - } & \text { Reduced } \\
\text { - } & \text { self-awareness } \\
\text { - } & \text { Self-critical } \\
& \text { Eager for approval }\end{array}$ & $\begin{array}{l}\text { - Liked by peers and } \\
\text { teachers } \\
\text { - } \quad \text { Apprehensive }\end{array}$ & $\begin{array}{ll}\text { - } & \text { Self-regulated } \\
\text { - } & \text { Able to set personal } \\
\text { goals } \\
\text { - } & \text { Avoids academic } \\
\text { risks } \\
\text { - }\end{array}$ \\
\hline
\end{tabular}

Students who demonstrate aspects of the Creative profile (Table 2), can often have negative reactions to teachers, peers, academic activity, and school. This connects specifically to the affective engagement dimension. Due to the strong connection of affective engagement to the behavioural dimension, this has implications for these students; meaning they could be less likely to be happy at school, which then potentially fatigues student learning and disconnects them further from education 
and school. A consequence of this can be limited mastery of the content due to restricted and reduced cognitive engagement (impacting on talent actualisation in Gagné's DMGT).

Table 2. Profile II Creative gifted profile characteristics mapped to the four engagement dimensions informed by the following references $[5,11,12,15]$.

\begin{tabular}{|c|c|c|c|c|c|}
\hline & Characteristics & $\begin{array}{l}\text { Behavioural } \\
\text { Engagement }\end{array}$ & Affective Engagement & Social Engagement & Cognitive Engagement \\
\hline $\begin{array}{l}\text { Profile II: } \\
\text { Creative }\end{array}$ & $\begin{array}{ll}\text { - } & \text { Highly creative } \\
\text { - } & \text { Readily bored } \\
\text { - } & \text { High energy } \\
\text { - } & \text { Impatient } \\
\text { - } & \text { Limited } \\
& \text { self-awareness } \\
\text { - } & \text { Limited self-control }\end{array}$ & $\begin{array}{ll}\text { - } & \text { Questions teachers } \\
\text { - } & \text { Questions rules } \\
\text { - } & \text { Honest and direct } \\
\text { - } & \text { Discipline issues } \\
\text { - } & \text { Impatient }\end{array}$ & $\begin{array}{ll}\text { - } & \text { Fluctuating } \\
\text { self-esteem } \\
\text { - } & \text { Psychologically } \\
& \text { vulnerable } \\
\text { - } & \text { Impulsive } \\
\text { - } & \text { Honest and direct } \\
\text { - } & \text { Easily bored and } \\
\text { frustrated }\end{array}$ & $\begin{array}{ll}\text { - } & \text { May conflict with } \\
\text { peers } \\
\text { - Seeks to fit in as } \\
\text { 'class clown' } \\
\text { - } \quad \text { Limited } \\
\text { interpersonal skills }\end{array}$ & $\begin{array}{ll}\text { - } & \begin{array}{l}\text { Persistent (in areas } \\
\text { of interest) }\end{array} \\
\text { - } & \text { Not seen as gifted } \\
\text { - } & \text { Underestimated } \\
\text { (by others) } \\
\text { - } & \begin{array}{l}\text { Creative } \\
\text { - }\end{array} \\
\text { Highly tolerant of } \\
\text { ambiguity }\end{array}$ \\
\hline
\end{tabular}

Students who may have characteristics of the third profile, Underground (Table 3), are frequently socially engaged, but can also be influenced by what is called the forced choice dilemma; a belief that some gifted students hold that they must choose between fitting in and being accepted by their peers, and achieving academically [22]. This can lead to underachievement and affective and cognitive disengagement.

Table 3. Profile III Underground gifted profile characteristics mapped to the four engagement dimensions informed by the following references $[5,11,12,15]$.

\begin{tabular}{|c|c|c|c|c|c|}
\hline & Characteristics & $\begin{array}{l}\text { Behavioural } \\
\text { Engagement }\end{array}$ & Affective Engagement & Social Engagement & Cognitive Engagement \\
\hline $\begin{array}{l}\text { Profile III: } \\
\text { Underground }\end{array}$ & $\begin{array}{ll}\text { - } & \begin{array}{l}\text { Diminished sense } \\
\text { of self }\end{array} \\
\text { - } & \text { Denies ability } \\
\text { - } & \text { Unsure of direction } \\
\text { - } & \text { Forced choice } \\
\text { dilemma } \\
\text { - } & \begin{array}{l}\text { Feelings } \\
\text { of insecurity }\end{array}\end{array}$ & $\begin{array}{ll}\text { - } & \text { Unsure of direction } \\
\text { - } & \text { Seen as quiet/shy } \\
\text { dilemma impacts } \\
\text { on effort, behaviour } \\
\text { and involvement in } \\
\text { school related } \\
\text { activities }\end{array}$ & $\begin{array}{ll}\text { - } & \text { Can be insecure } \\
\text { - } & \text { Internalises } \\
\text { conflicts } \\
\text { - } & \text { Often anxious } \\
\text { - } & \text { Guilt about forced } \\
\text { choice dilemma }\end{array}$ & $\begin{array}{ll}\text { - } & \text { Strongly desires } \\
\text { social belonging } \\
\text { - } & \text { Unsettled in } \\
\text { peer group } \\
\text { - } & \text { Disconnected } \\
\text { from school } \\
\text { - } & \text { Hides abilities to fit } \\
\text { in with peers } \\
\text { (forced choice } \\
\text { dilemma) }\end{array}$ & $\begin{array}{l}\text { Ambivalent about } \\
\text { achievement } \\
\text { Views some } \\
\text { achievements as } \\
\text { betrayal of peer } \\
\text { group (forced } \\
\text { choice dilemma) } \\
\text { Rejects challenge }\end{array}$ \\
\hline
\end{tabular}

The At-Risk gifted profile (Table 4), suggests that students who primarily exhibit these characteristics can be physically present in the classroom (behaviourally engaged), but affectively, socially and cognitively they have become disengaged and consequently disconnected from learning [11]. When gifted students become detached from their peers, learning, and school, this compounds the effect on the other engagement dimensions across the cyclical model. Students who display characteristics of the At-Risk profile can subsequently refuse to participate in class tasks and negatively express their emotions resulting in increased behavioural issues in the classroom [11] and increasingly becoming behaviourally (and consequently affectively, socially, and cognitively) disengaged. 
Table 4. Profile IV At-Risk gifted profile characteristics mapped to the four engagement dimensions informed by the following references $[5,11,12,15]$.

\begin{tabular}{|c|c|c|c|c|c|}
\hline & Characteristics & $\begin{array}{l}\text { Behavioural } \\
\text { Engagement }\end{array}$ & Affective Engagement & Social Engagement & Cognitive Engagement \\
\hline $\begin{array}{l}\text { Profile IV: } \\
\text { At-Risk }\end{array}$ & 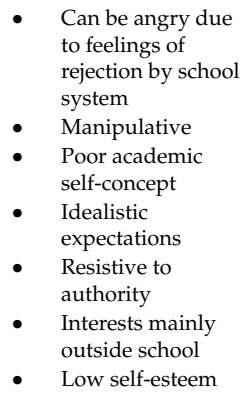 & $\begin{array}{ll}\text { - } & \text { Can be disruptive } \\
\text { - } & \text { Thrill-seeking } \\
\text { - } & \text { Irregular } \\
& \text { attendance } \\
\text { - } & \text { Seen as defiant } \\
\text { - } & \text { Physically present } \\
& \text { but affectively and } \\
\text { cognitively } \\
\text { disengaged } \\
\text { - Can respond } \\
\text { defensively }\end{array}$ & $\begin{array}{ll}\text { - } & \text { Defensive } \\
\text { - } & \text { Critical of self and } \\
\text { others } \\
\text { - Withdrawn }\end{array}$ & $\begin{array}{ll}\text { - } & \text { Often rejected by } \\
& \text { peers } \\
\text { - } & \text { Resistive to } \\
& \text { authority } \\
\text { - } & \text { Can be antisocial } \\
\text { - } & \text { Self-isolating } \\
\text { - } & \text { Poor peer } \\
& \text { relationships in } \\
& \text { school }\end{array}$ & $\begin{array}{ll}\text { - } & \text { Creative } \\
\text { - } & \text { Not motivated for } \\
& \text { teacher-driven } \\
\text { - } & \text { extrinsic rewards } \\
& \text { Limited academic } \\
\text { - } & \text { Inchievement } \\
\text { - } & \text { Low performance } \\
\text { - } & \text { Pursues interests } \\
& \text { outside school }\end{array}$ \\
\hline
\end{tabular}

Students who may display characteristics of the Twice-Exceptional profile (Table 5), are students who have two exceptionalities—giftedness and one or more disabilities [23]. Twice-exceptional students can have multiple comorbid disabilities, such as autism spectrum disorders, dyslexia, anxiety, and dysgraphia. Students with this profile can have reduced resilience (impacting on behavioural engagement), limited coping strategies and learning strategies (inhibiting cognitive engagement), and impeded persistence (hindering both behavioural and cognitive engagement).

Table 5. Profile IV Twice-Exceptional gifted profile characteristics mapped to the four engagement dimensions informed by the following references $[5,11,12,15]$.

\begin{tabular}{|c|c|c|c|c|c|}
\hline & Characteristics & $\begin{array}{l}\text { Behavioural } \\
\text { Engagement }\end{array}$ & Affective Engagement & Social Engagement & Cognitive Engagement \\
\hline $\begin{array}{l}\text { • } \\
\text { Profile V: } \\
\text { Twice-Exceptional } \\
\bullet \\
\bullet\end{array}$ & 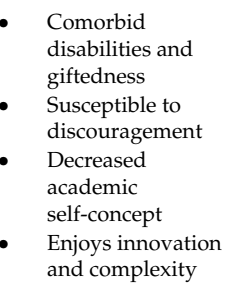 & $\begin{array}{ll}- & \text { Off-task } \\
\text { - } & \text { Disorganised } \\
\text { - } & \text { Processing } \\
& \text { difficulties (e.g., } \\
& \text { auditory) } \\
\text { - } & \text { May appear } \\
& \text { disruptive }\end{array}$ & $\begin{array}{ll}\text { - } & \text { Learned } \\
& \text { helplessness } \\
\text { - } & \text { Limited } \\
\text { perseverance } \\
\text { - } & \text { Limited coping } \\
\text { strategies }\end{array}$ & $\begin{array}{l}\text { Do not know where } \\
\text { they belong } \\
\text { May not be able to } \\
\text { cope with gifted } \\
\text { peer group } \\
\text { May feel 'dumbed } \\
\text { down' by inclusion } \\
\text { in pull out } \\
\text { programs to target } \\
\text { disabilities }\end{array}$ & $\begin{array}{ll}\text { - } & \text { Working memory } \\
& \text { issues } \\
\text { - } & \text { Makes } \\
\text { interdisciplinary } \\
\text { connections easily } \\
\text { - } \quad \text { Inconsistent work } \\
\text { - } \quad \text { Good problem } \\
\text { solvers } \\
\text { - } \quad \begin{array}{l}\text { Underestimated for } \\
\text { potential }\end{array}\end{array}$ \\
\hline
\end{tabular}

Gifted students who predominantly exhibit characteristics of the Autonomous profile (Table 6), includes learners who are mostly engaged across the cyclical model. These students have worked out what is needed to perform well in school. They are generally self-directed, confident learners, often well-respected by peers and teachers. However, these students need additional support to develop their gifted potential. They can often be underachieving because they have reached the learning ceiling, where educators believe that these students have met the year level learning outcomes, and therefore, their learning and achievement is sufficient. Extending student motivation to excel is a challenge for both the learner and teacher. However, if they were appropriately challenged with above-level content and relevant learning opportunities they may demonstrate accelerated achievement. 
Table 6. Profile VI Autonomous gifted profile characteristics mapped to the four engagement dimensions informed by the following references $[5,11,12,15]$.

\begin{tabular}{|c|c|c|c|c|c|}
\hline & Characteristics & $\begin{array}{l}\text { Behavioural } \\
\text { Engagement }\end{array}$ & Affective Engagement & Social Engagement & Cognitive Engagement \\
\hline $\begin{array}{c}\text { Profile VI: } \\
\text { Autonomous }\end{array}$ & $\begin{array}{ll}\text { - } & \text { Self-confident } \\
\text { - } & \text { Self-accepting } \\
\text { - } & \text { Ambitious and } \\
& \text { excited } \\
\text { - } & \text { Resilient } \\
\text { - } & \text { Strong self-concept }\end{array}$ & $\begin{array}{ll}- & \text { Optimistic } \\
- & \text { May not view } \\
\text { academics as a } \\
\text { priority }\end{array}$ & $\begin{array}{ll}\text { - } & \text { Intrinsically } \\
\text { motivated } \\
\text { - } & \text { Good at } \\
\text { self-regulation } \\
\text { - } & \text { Follows areas of } \\
\text { passion }\end{array}$ & $\begin{array}{ll}\text { - } & \text { Good social skills } \\
\text { - } & \text { Thrives in diverse } \\
\text { environments } \\
\text { - } & \text { Shows tolerance } \\
\text { and respect for } \\
\text { others } \\
\text { - } \begin{array}{l}\text { Well-liked by peers } \\
\text { and teachers }\end{array}\end{array}$ & $\begin{array}{ll}\text { - } & \text { Strongly } \\
\text { - } & \text { self-directed } \\
\text { - } & \text { Seeks challenge } \\
& \text { Willing to fail and } \\
& \text { learn from it }\end{array}$ \\
\hline
\end{tabular}

The intrinsic connections to Neihart and Betts' [5] six gifted profiles and the cyclical model of the four interrelated engagement dimensions has been made evident here. It is important to now turn our attention to some appropriate pedagogical opportunities and approaches that can foster gifted student (re)engagement in school and learning.

\section{Pedagogical Opportunities For (Re) Engaging Gifted Students}

The (re)engagement needs for each of Neihart and Betts' [5] six gifted profiles presents important opportunities for educators to individually (re)engage these students, and at the same time attempt to address disengagement and underachievement. As illustrated in Table 7, examples of pedagogical approaches specific to each learner profile have been provided along with specific connections to relevant dimensions of learner engagement (behavioural, affective, social, and cognitive). This conceptualisation highlights for educators the critical connection between these three components (engagement dimensions, learner profile characteristics, and pedagogical approaches). Through a range of purposeful pedagogical approaches, gifted students can be provided with individualised support and personalised learning experiences to become (re)engaged learners.

The common theme across the pedagogical approaches outlined in Table 7, is that many of these approaches foster the opportunities for the development of student self-regulation. As a key core skill required for academic performance, self-regulation is an important influencing factor on student engagement across the four engagement dimensions [24]. Drawn from social cognitive theory, self-regulated learning involves students being cognitively, motivationally, and behaviourally engaged, actively participating in academic tasks, and involved in school-related activities [25].

Prior to approaching any learning opportunity, students need to be orientated to engage with the task, set goals to direct their efforts, focus their attention, and be supported to self-assess their own learning (elements of self-regulated learning). These can be achieved in many ways, for example, through providing freedom and autonomy in learning focused on areas of interest (see examples in Table 7). Pedagogical approaches which foster interest in the task (or content), and show the value or importance of the task, support student engagement across the four engagement dimensions. Through these types of approaches it is important that educators monitor and support gifted students in developing requisite skills and strategies for engaging with learning opportunities. For example, students need to develop and know which strategies to draw on for specific kinds of learning, for instance studying for an exam requires knowledge and application of study skills (e.g., revision and use of flash cards) [26]. Opportunities for learner self-reflection need to be embedded in the approaches outlined in Table 7, so that gifted students can reflect on whether they have met their goals or not and are able to explain (through self-reflection) the how and why. Self-reflection influences and supports goal setting, motivation, and persistence for future learning [26]. In this way, past learning and prior levels of student engagement have a strong and significant influence on future learner engagement (as illustrated in Figure 1). 
Table 7. (Re) Engagement Opportunities for each profile informed by the references $[5,11])$.

\begin{tabular}{|c|c|}
\hline Profile & Some Pedagogical Approaches for (Re)Engagement across the Four Dimensions \\
\hline Successful & $\begin{array}{l}\text { - } \quad \text { Freedom to make choices (Cognitive); } \\
\text { - } \quad \text { Risk-taking activities (Behavioural and Cognitive); } \\
\text { - } \quad \text { Provilenging tasks (Cognitive); } \\
\text { - } \quad \text { Opportunities for demonstrating leadership in the classroom and school (Social); } \\
\text { - } \quad \text { Provide opportunities to build self-confidence and assertiveness (e.g., through games/role play activity with peers) } \\
\text { - } \quad \text { Opfective and Social); } \\
\text { - Foster intrinsic motivation following achievement rather than external reinforcement or excessive praise (Behavioural). }\end{array}$ \\
\hline Creative & $\begin{array}{l}\text { - } \quad \text { Provide group work tasks and collaborative activities (Social and Cognitive); } \\
\text { - Allow diverse and innovative opportunities so that students can express themselves through creative ways (Behavioural, } \\
\text { - } \quad \text { Value and promote student self-awareness and self-belief (e.g., mindfulness programs) (Affective and Cognitive); } \\
\text { - } \quad \text { Demonstrate how to resist peer pressure (Behavioural, Affective and Social); } \\
\text { - } \quad \text { Practice interpersonal skills and social emotional development (Behavioural, Affective, and Social); } \\
\text { - } \quad \text { Increase confidence and communication skills (Behavioural, Affective, Social, and Cognitive); } \\
\text { - } \quad \text { Encovide mentors and role-models (Behavioural, Affective, Social and Cognitive); } \\
\text { - Be respectful of student autonomy, decisions and individual learning choices (Behavioural, Affective, Social, } \\
\text { and Cognitive). }\end{array}$ \\
\hline Underground & $\begin{array}{l}\text { - Scaffold and extend abilities across all learning areas (Behavioural, Affective, Social and Cognitive); } \\
\text { - Provide students with diverse, gifted, and positive role models from different backgrounds (Behavioural, Affective, Social, } \\
\text { and Cognitive); } \\
\text { - Foster belief in themselves and self-identity (Behavioural, Affective, Social, and Cognitive); } \\
\text { - Provide support for future career and post-school planning/study opportunities (Behavioural, Affective, Social, } \\
\text { and Cognitive); } \\
\text { - } \quad \text { Model being a lifelong learner and facilitator of learning (Cognitive); } \\
\text { - } \quad \text { Suppourage student voice and provide regular reassurance (Behavioural, Affective, Social, and Cognitive); } \\
\text { - Value independence and positive learning choices (Behavioural and Cognitive). }\end{array}$ \\
\hline At-Risk & $\begin{array}{l}\text { - Provide a safe and structured classroom environment and schedule (Behavioural and Cognitive); } \\
\text { - } \quad \text { Offer a range of well-being supports that can nurture relationships with others (Affective and Social); } \\
\text { - } \quad \text { Pesign personalised learning programs based on student interests (Cognitive); } \\
\text { - } \quad \text { Givide oppositunities for learning accountability and responsibility (Behavioural, Affective, Social, and Cognitive); } \\
\text { - } \quad \text { Affective, and Cognitive); }\end{array}$ \\
\hline Twice-exceptional & $\begin{array}{l}\text { - Focus on strengths and skills utilising a non-deficit approach (Behavioural Affective, and Cognitive); } \\
\text { - } \quad \text { Support perseverance with completing tasks (Behavioural, Affective and Cognitive); } \\
\text { - } \quad \text { Provide strategies to help overcome learning obstacles (Behavioural, Affective, and Cognitive); } \\
\text { - } \quad \text { Help student voice and agency (Behavioural, Affective, Social and Cognitive); } \\
\text { - } \quad \text { Affective, Social, confident in their self-identity and self-concept so they can advocate for themselves (Behavioural, } \\
\text { - } \quad \text { Recognition of their gifts is clear to all and this is affirmed and re-affirmed (Behavioural, Affective, and Cognitive); } \\
\text { - Reduce risks of distractions during learning and support learner self-control and self-regulation capabilities (Behavioural, } \\
\text { - } \quad \text { Pffective, and Cognitive); }\end{array}$ \\
\hline Autonomous & $\begin{array}{l}\text { - Give students additional and extended support where needed (Behavioural, Affective, Social, and Cognitive); } \\
\text { - Provide inspirational resources to nurture and facilitate learning and growth in areas of interest (Behavioural, Affective, } \\
\text { and Cognitive); } \\
\text { Foster motivation for extending learning along with positive and constructive feedback Behavioural, Affective, } \\
\text { and Cognitive); } \\
\text { - Provide academic risk-taking and challenging contexts (Behavioural, Affective, and Cognitive); } \\
\text { - Open communication and connection with students from a range of year levels to foster their leadership and mentorship } \\
\text { capabilities (Social and Cognitive); } \\
\text { - Provide freedom and autonomy through student access to diverse, different and stimulating learning spaces (Behavioural, } \\
\text { Affective, Social, and Cognitive); } \\
\text { - Encourage engagement through team building activities and collaborative class projects (Social and Cognitive). }\end{array}$ \\
\hline
\end{tabular}

By embedding such pedagogical approaches as those outlined in Table 7, educators can be empowered to foster gifted students' abilities to set goals and also support them in recognising when to use the different strategies they have developed through these approaches, thus enabling a transformation of their abilities into academic skills [27] or talents. Developing self-regulation strategies enables gifted students to be actively participating in their own learning, which in turn 
facilitates the development and practice of elements across the four engagement dimensions, such as effort, persistence, interest, enjoyment, and volition learning.

It is important to recognise that each gifted learner is an individual, therefore it is critical to leverage pedagogical approaches, such as those outlined in Table 7, in a personalised way, so that each student receives targeted support for (re)engagement. Teachers already apply differentiated instruction through a variety of pedagogical approaches that are aimed at modifying the regular curriculum to suit gifted learners [28]. However, the ultimate aim of (re)engaging gifted students is to personalise their learning. Similar to differentiation, personalised learning focuses on the needs of individual gifted students, however unlike differentiation, which starts with broad curriculum and adjusts this to suit individual gifted learners, personalised learning begins with the individual gifted student (based on the Neihart and Betts broad profiles), rather than the curriculum [28]. In this way, each gifted student becomes the driver of their own learning, supported by a skilled teacher implementing some of the types of approaches outlined in Table 7. This is the crux of gifted students' (re)engagement-by personalising learning for gifted students, expert teachers can support engagement across all of the broad gifted profiles (i.e., Neihart and Betts), and target specific (re)engagement opportunities based on individual needs for each gifted learner. For example, personalised learning can target self-regulation-a characteristic of the Twice-Exceptional broad gifted profile, and an element of the cognitive engagement dimension, which needs addressing for learners with this profile. Furthermore, personalised learning can also focus on developing learner autonomy. This is highlighted in the Successful, Creative, and Autonomous gifted profiles [5], and is an element that needs addressing using the Cognitive engagement dimension for each of these broad profiles. Likewise, personalised learning approaches can also address the need for engagement through self-directed learning where all six Neihart and Betts' [5] broad gifted learner profiles can be addressed. Thus, at the same time targeting the cognitive engagement dimension, often required for these learners to be successful in reaching their potential: demonstrating talent through mastery (exemplified in Gagné's DMGT) [6].

It is important to note that what we propose here, with targeted personalised learning approaches for each gifted student, is vastly different to individualised learning, which can mean individual students learning separately from their peers [28], often isolated and at-risk of becoming behaviourally, affectively, socially, and cognitively disengaged. Personalised learning is therefore, focused on and tailored to the individual abilities, interests, aspirations, and needs of each gifted student. Hence, each student is engaged in becoming self-directed and monitors his or her own progress towards mastery (cognitive engagement) and transforming giftedness into talent as demonstrated in Gagné's DMGT [6] through mastery. Understanding that each of the four engagement dimensions, the individual gifted learner profile, and appropriate, targeted, and personalised pedagogical approaches are interrelated, is essential to supporting the (re)engagement of gifted learners. Figure 2 conceptualises this connectedness, showing the nuanced dependency of each component of the (re)engagement nexus at the centre of the three components (consisting of the engagement dimensions, individual gifted learner profile, and personalised pedagogical approaches), which enable individual learners to be consistently engaged at school to address underachievement and disengagement. 


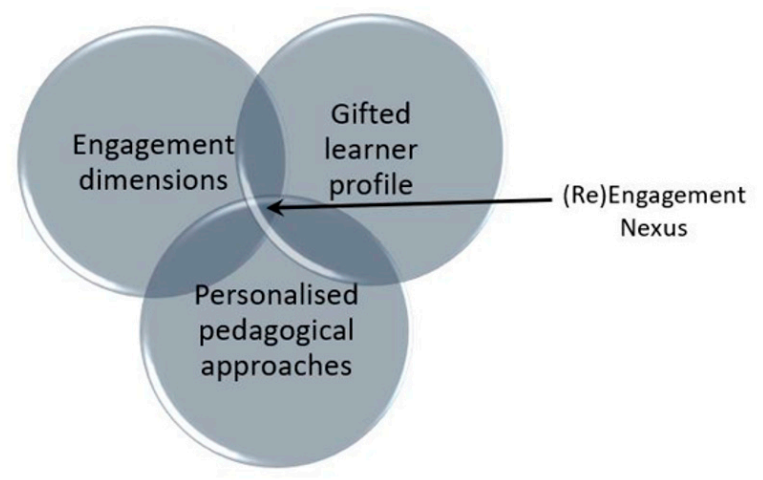

Figure 2. The (Re) Engagement Nexus Model.

Our (Re) Engagement Nexus Model (Figure 2), suggests a conceptualisation of the interrelationship between the three components: the engagement dimensions; gifted learner profiles; and personalised pedagogical approaches. This provides the framework from which to view the nexus of personalised (re)engagement opportunities for gifted learners. The three components provide a promising lens from which to view re (engagement) of gifted students in the classroom. The exploration of the interrelationships between these three components highlights the important need for teachers and researchers to consider how these guide teaching and learning decisions for re (engaging) gifted students. This approach in turn has the potential to enable personalised learning experiences. We propose the (Re)Engagement Nexus Model as a starting point for future research approaches that drill down at classroom and individual gifted student level, to explore what this may mean in terms of actual classroom practices for addressing gifted learner underachievement and disengagement. It is hoped that this conceptual model will support further research endeavours aimed at (re)engaging gifted learners and preventing underachievement and disengagement before it becomes entrenched.

Author Contributions: Conceptualisation, M.R.-P.; Methodology, M.R.-P. and M.M.N.; Writing—original draft, M.R.-P. and M.M.N.; Writing-review \& editing, M.R.-P. and M.M.N. All authors have read and agreed to the published version of the manuscript.

Funding: This research received no external funding.

Conflicts of Interest: The authors declare no conflict of interest.

\section{References}

1. Dai, D.Y.; Swanson, J.A.; Cheng, H. State of research on giftedness and gifted education: A survey of empirical studies published during 1998-2010 (April). Gift. Child. Q. 2011, 55, 126-138. [CrossRef]

2. Bennett-Rappell, H.; Northcote, M. Underachieving gifted students: Two case studies. Issues Educ. Res. 2016, 26, 407-430.

3. Landis, R.N.; Reschly, A.L. Reexamining gifted underachievement and dropout through the lens of student engagement. J. Educ. Gift. 2013, 36, 220-249. [CrossRef]

4. McCormack, K.M.; Plucker, J.A. Connecting student engagement to the academic and social needs of gifted and talented students. In Creatively Gifted Students are not like Other Gifted Students: Research, Theory, and Practice; Baer, J., Sriraman, B., Eds.; Sense Publishers: Rotterdam, The Netherland, 2013; pp. 121-136.

5. Neihart, M.; Betts, G. Revised Profiles of the Gifted and Talented. Available online: https://sciencetalenter. dk/sites/default/files/revised_profiles_of_the_gifted_and_talented_-_neihart_and_betts.pdf (accessed on 8 July 2020).

6. Gagné, F. The DMGT: Changes within, beneath, and beyond. Talent. Dev. Excell. 2013, 5, 5-19.

7. Merrotsy, P. Gagné's Differentiated Model of Giftedness and Talent in Australian Education. Australas. J. Educ. Gift. 2017, 26, 30-42. [CrossRef] 
8. Goss, P.; Sonnemann, J. Engaging Students: Creating Classrooms that Improve Learning. Available online: https://grattan.edu.au/wp-content/uploads/2017/02/Engaging-students-creating-classrooms-that-improvelearning.pdf (accessed on 5 August 2020).

9. Morawska, A.; Sanders, M.R. Parenting gifted and talented children: Conceptual and empirical foundations. Gift. Child. Q. 2009, 53, 163-173. [CrossRef]

10. Deloitte Access Economics. School Quality in Australia: Exploring the Drivers of Student Outcomes and the Links to Practice and Schooling Quality. Available online: https://www.education.gov.au/school-qualityaustralia-exploring-drivers-student-outcomes-and-links-practice-and-schooling-quality (accessed on 19 August 2020).

11. Australian Capital Territory (ACT). Gifted and Talented Gifted Underachievers1gifted and Talented Education. Available online: https://www.education.act.gov.au/_data/assets/pdf_file/0009/587304/GiftedUnderachievers.pdf (accessed on 7 July 2020).

12. Bowden, J.; Bowden Tickle, L.; Naumann, K. The Four Pillars of Tertiary Student Engagement and Success: A Holistic Measurement Approach. Available online: https://www.tandfonline.com/doi/full/10.1080/03075079. 2019.1672647 (accessed on 10 October 2019).

13. Carvourand, M.L.; Chiu, A. A Cyclical approach to continuum modeling: A conceptual model of diabetic foot care. Public Health Front. 2017, 5, 1-7.

14. Gibbs, R.; Poskitt, J. Student engagement in the middle years of schooling (Years 7-10): A literature review. Report to the Ministry of Education. Available online: http://citeseerx.ist.psu.edu/viewdoc/summary?doi=10.1. 1.475.5394 (accessed on 27 September 2020).

15. Neumann, M.; Ronksley-Pavia, M. Leveraging digital technologies for (re)engaging gifted students in the middle years. Aust. J. Middle Sch. 2020, in press.

16. D’Errico, F.; Paciello, M.; Cerniglia, L. When emotions enhance students' Engagement in E-Learning Processes. J. e-Learn. Knowl. Soc. 2016, 12, 9-23.

17. D'Errico, F.; Paciello, M.; De Carolis, B.N.; Vattani, A.; Palestra, G.; Anzivino, G. Cognitive emotions in E-learning processes and their potential relationship with students' academic adjustment. Int. J. Emot. Educ. 2018, 10, 89-111.

18. McIntyre, J.C.; Worsley, J.; Corcoran, R.; Woods, P.H.; Bentall, P.R. Academic and non-academic predictors of student psychological distress: The role of social identity and loneliness. J. Ment. Health. 2018, 27, 230-239. [CrossRef] [PubMed]

19. Makel, M.C.; Matthews, M.S.; Peters, S.J.; Rambo-Hernandez, K.; Plucker, J.A. How Can so Many Students Be Invisible? Large Percentages of American Students Perform above Grade Level. Available online: https:// edpolicy.education.jhu.edu/wp-content/uploads/2016/08/StudentsinvisiblemastheadFINAL.pdf (accessed on 5 August 2020).

20. Gross, M.U.M. Gifted and Talented Education Professional Development Package for Teachers: Extension Module 1 Secondary. Available online: https://docs.education.gov.au/system/files/doc/pdf/ extension_mod1_secondary.pdf (accessed on 27 August 2020).

21. Siegel, D.; DaVia Rubenstein, L.; McCoach, B. Do you know what I'm thinking? A comparison of teacher and parent perspectives of underachieving gifted students' attitudes. Psychol. Sch. 2020, 57, 1596-1614. [CrossRef]

22. Jung, J.Y.; McCormick, J.; Gross, M.U.M. The forced choice dilemma: A model incorporating idiocentric/allocentric cultural orientation. Gift. Child. Q. 2012, 56, 15-24. [CrossRef]

23. Ronksley-Pavia, M. A model of twice-exceptionality: Explaining and defining the apparent paradoxical combination of disability and giftedness in childhood. J. Educ. Gift. 2015, 38, 318-340. [CrossRef]

24. Antúnez, A.; del Henar Pérez-Herrero, M.; Rosário, P.; Vallejo, G.; Núñez, J.C. Engagement SPIRALS in elementary students: A school-based self-regulated learning approach. Sustainability 2020, 12, 1-22. [CrossRef]

25. Dent, A.L.; Koenka, A.C. The Relation between Self-Regulated Learning and Academic Achievement across Childhood and Adolescence: A Meta-Analysis. Educ. Psychol. Rev. 2016, 28, 425-474. [CrossRef]

26. Ridgley, L.M.; DaVia Rubenstein, L.; Callan, G.L. Gifted underachievement within a self-regulated learning framework: Proposing a task-dependent model to guide early identification and intervention. Psychol. Sch. 2020, 57, 1365-1384. [CrossRef] 
27. Zimmerman, B.J. Becoming a self-regulated learner: An overview. Theory Pract. 2002, 41, 64-70. [CrossRef]

28. Ronksley-Pavia, M. Personalised learning: Disability and gifted learners. In Teaching Primary Years: Rethinking Curriculum, Pedagogy, and Assessment; Pendergast, D., Main, K., Eds.; Allen \& Unwin: Crows Nest, Australia, 2019; pp. 422-442.

(C) 2020 by the authors. Licensee MDPI, Basel, Switzerland. This article is an open access article distributed under the terms and conditions of the Creative Commons Attribution (CC BY) license (http://creativecommons.org/licenses/by/4.0/). 